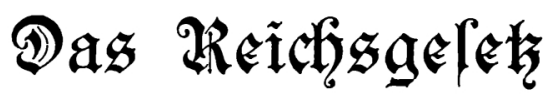

betreffertid die

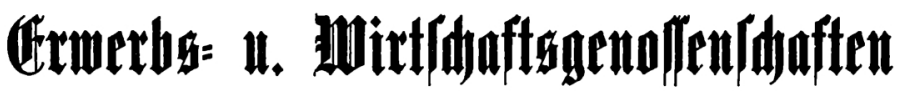 vom 1. Mlai 1889 .}

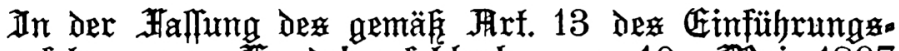

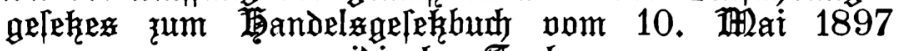
revidierfen đextes.

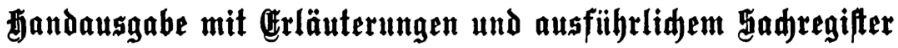
$\mathfrak{n o n}$

\section{Griedrid Z\$on/dana,}

Borjtandsmitglied der Bayer. Lautomirtfáajtabanf.

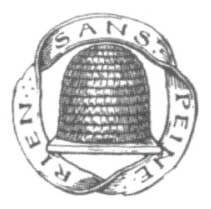

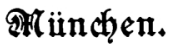

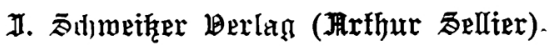
1899. 
